\title{
Evaluation of the Degree of Pollution of the Ground Water Resources in Sedimentary Formations: Case of the Localities of Bingerville (Côte D'ivoire)
}

\author{
Kanohin Fulvie Épse Otchoumou ${ }^{1}$, Bonny Aya Carole ${ }^{2}$, Atta Xavier Ulrich ${ }^{3}$, Yapo Ossey Bernard ${ }^{4}$, \\ Goné Droh Lanciné ${ }^{5}$, Savane Issiaka ${ }^{6}$
} ${ }^{1,3,5,6}$ Laboratory of Geosciences and Environment, Unit of Training and research in Science and Management of the Environment, Nangui
Abrogoua University, Abidjan, Côte d'Ivoire.

\footnotetext{
${ }^{2}$ Laboratory of Sciences and Technology of Water and the Environment, Unit of Training and Research in Sciences of the Earth and the Mining Resources, Felix Houphouet-Boigny University, Abidjan, Côte d'Ivoire.

${ }^{3,4}$ Laboratory of sciences of the Environment, Unit of Training and Research (UFR) of Sciences and Management of the Environment, University Nangui Abrogoua, Côte d'ivoire
}

\begin{abstract}
The access to drinking water in the rural zones constitutes a major concern for the authorities because of the quality of the water consumed by the village communities. The objective of this study is to assess the quality of the water intended for human consumption in the localities of Bingerville. Adopted methodology consisted in evaluating the level of pollution by the follow-up of the space variation of the contents of the various pollutants. Statistical tests were carried out to determine the probable origin of the pollutants met. A bacteriological analysis was carried out to evaluate the level of contamination of these resources. The results show that the contents of certain parameters, sources of pollution, remain high and often largely above standards WHO. The parameters more threatening remain the phosphate $\left(\mathrm{PO42}^{-}\right)$and ammonium $\left(\mathrm{NH}^{+}\right)$. The results of the statistical tests reveal two major phenomena which are the pollution of surface origin represented by factor $2\left(F_{2}\right)$ and mineralization on the level of factors 2 and 3 ( $F_{2}$ and $\left.F_{3}\right)$. The indicators of pollution ( $\mathrm{PO}^{2-}, \mathrm{NH}^{+}$and $\mathrm{NO}_{3}{ }^{-}$) observed on the level of factor 1 show that the pollutants which threaten quality of these resources could come from the septic tanks as well as sites of breeding. These results are confirmed by the bacteriological tests through the proportioning of nutritive salts which made it possible to identify and count fecal and total Coliforms, fecal Streptococcusas well as Clostridium perfringens. The presence of these parameters makes these water resources unfit for consumption.
\end{abstract}

Keywords: Groundwater, dissolved salts, fecal pollution, Bingerville, Côte d'Ivoire

\section{Introduction}

Water is an invaluable and essential natural resource for multiple uses. Its use at food ends or of hygiene requires an excellent physicochemical and microbiological quality. Studies undertaken in Côte d'Ivoire in urban environment by $[11,14,18,27]$ allowed to characterize precarious districts of Abidjan's well waters of domestic use and to highlight the sources of pollution of these wells. The results of this work reveal an ammonium, phosphatesand nitratewell polluted water with contents higher than the guide's values of WHO. The large African cities exploit the deep nap to feed out of water. In rural region, the localities exploit the ground water through the wells and the sources. However this ground water is exposed to pollution due to the anthropic activities. The access to the services of cleansing being non-existent in rural region, the drainage of worn waters and excreta of these villages is carried out in great majority by traditional latrines non-returnable making the ground water vulnerable to pollution. It is thus significant to have a better knowledge of the exploited nap, especially information concerning, the quality of water and the protection measures of its resources [7]. In the area of Bingerville, selected studied zones, and precisely the villages of Anan and Agban, wells, sources, and drillings are the principal sources of supply drinking water of the local populations. It is thus advisable to give a detailed attention to the problem of pollution of this water of domestic use.

\section{Material and Methods}

\subsection{Presentation of the zone of study}

Bingerville (figure 1) is located at the south-east of Côte d'Ivoire between longitudes $3^{\circ} 53^{\prime}$ and $3^{\circ} 54^{\prime}$ and latitudes $5^{\circ} 21^{\prime}$ and $5^{\circ} 22^{\prime}$, with an average altitude of $35 \mathrm{~m}$. the city built itself on a hill culminating at the altitude of approximately $96 \mathrm{~m}$ and going down towards the Ebrié lagoon, in the south, with steep slopes. It counts 91319 inhabitants, according to the General recencement of the human population result of 2014 
International Journal of Science and Research (IJSR)

ISSN (Online): 2319-7064

Index Copernicus Value (2016): 79. 57 | Impact Factor (2015): 6. 391

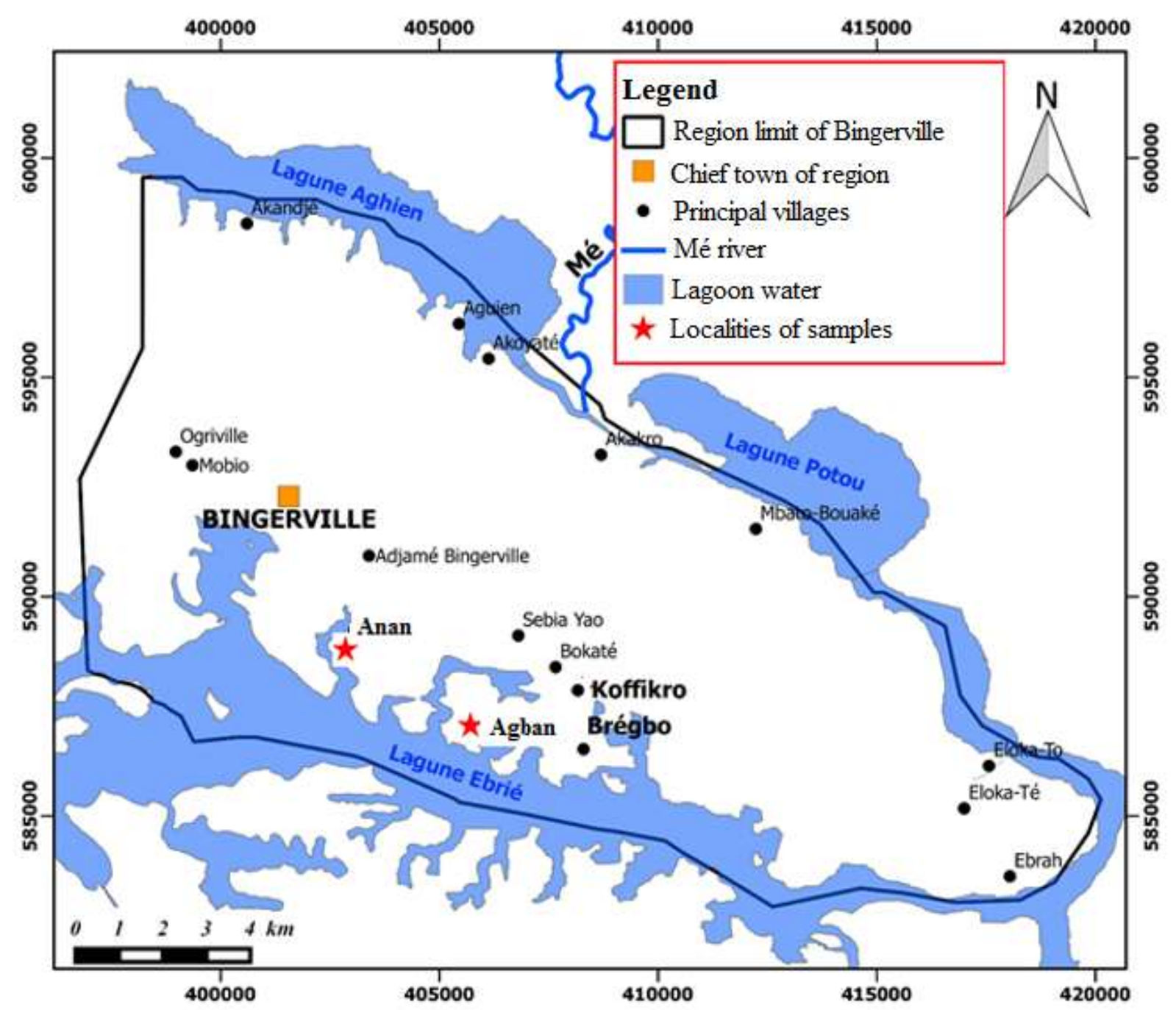

Figure 1: Geographical situation of Bingerville

The localities prospected, Agban and Anan belong to the region of Bingerville located at the South of Côte d'Ivoire (Figure 1). Bingerville covers a surface of $2119 \mathrm{~km}^{2}$ and its population is estimated at 91319 inhabitants [17]. During prospections and wells sampling campaigns in the villages of Bingerville (Anan, Agban, Adjamé-bingerville, Danhokro, Elokaté, Elokato, Santè, Brègbo and Koffikro), the report reveals the presence of functional water towers in almost all the villages. However the surveys carried out near the populations reveal the use of well water by themselves for the detergent, the crockery and even for consumption in the case of breakdown of the water towers allotted by the district of Abidjan. These two villages were selected to analyze the dangers to which the populations are exposed while feeding with water vulnerable to pollution. Anan and Agban were located at $4 \mathrm{~km}$ and $7 \mathrm{~km}$ from Bingerville respectively (Figure 2). These two localities cover a surface of approximately $80 \mathrm{~km}^{2}$ and their population is estimated at 3500 inhabitants [17]. The zone of study profits from a climate characterized by two rainy seasons alternated by two dry seasons with an annual rainfall of average $1800 \mathrm{~mm}$. The annual rainfalls (2005-2015) of the station of Bingerville were obtained from the Airport Company of Weather Development (SODEXAM). Bingerville belongs to the sedimentary basin of the Continental Terminal (southern of the country), and primarily consists of clayey sands and sandstone dating from the tertiary sector, precisely of the pliocene [23]. On the morphological level, this area belongs to the zone known as of the "high plateaus" which occupies the Northern part of the lagoon system, of which substratum, made of clayey sands, generated a relief with soft and undulating forms, where the significant accidents are rare and altitudes, lower than $100 \mathrm{~m}$ [5]. Bingerville is drained by two lagoons, the Aghien lagoon and the Ebrié lagoon. 


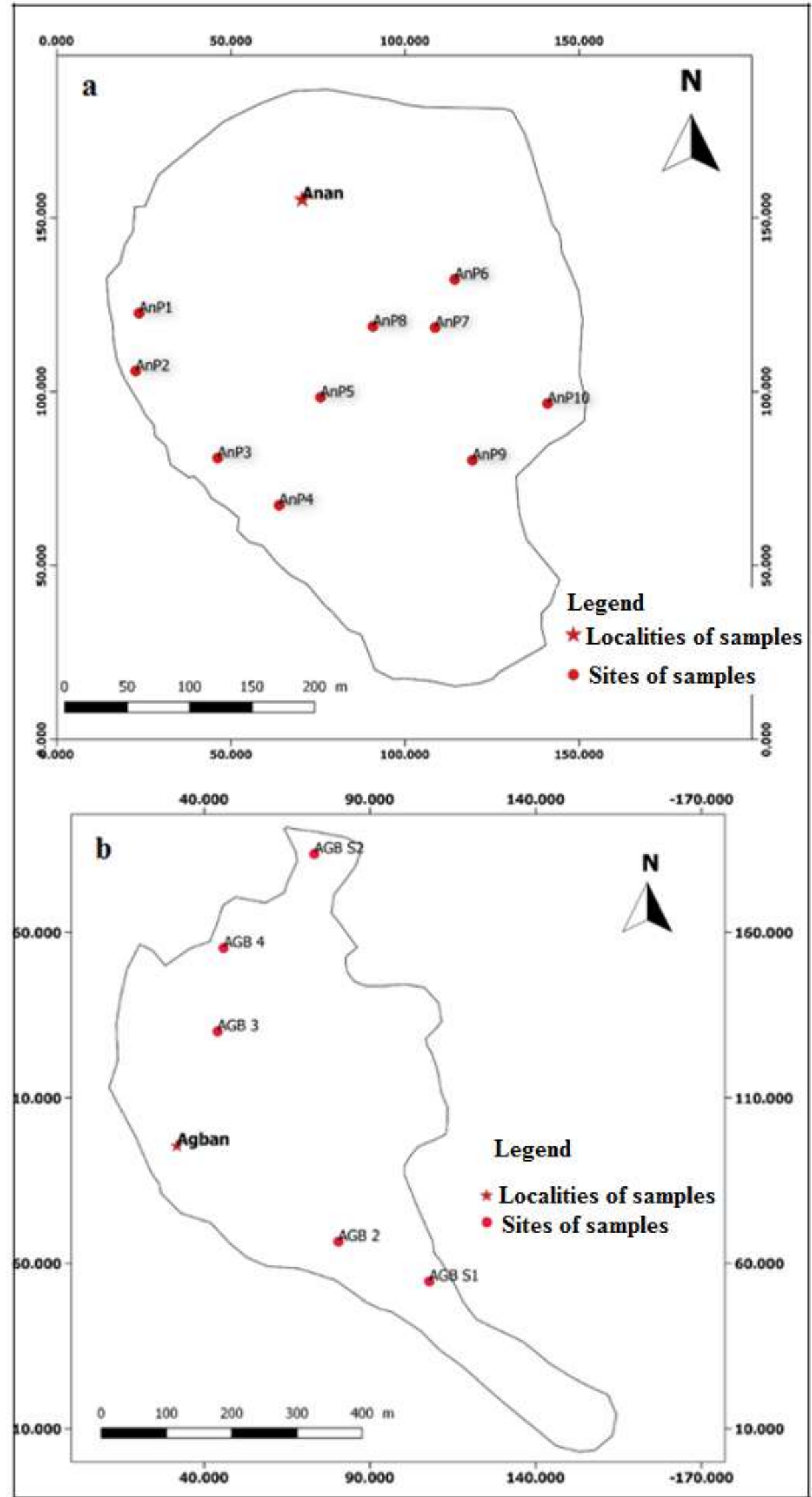

Figure 2: Presentation of the sampled localities:Anan (a) and Agban (b)

\subsection{Material of Study}

Field works proceeded in the region of Bingerville, precisely in the villages of Anan and Agban. On the field, a "garminetrex 30" GPS was used to determine the geographical co-ordinates of the intake points of water; an electric sound probe piezometer was used to take the various water levels in the wells; one decameter was used to measure the distances between the wells and the zones likely to be at the origin of one supposed pollution. The taking

\section{Volume 6 Issue 12, December 2017}

www. ijsr. net 


\section{International Journal of Science and Research (IJSR) \\ ISSN (Online): 2319-7064}

Index Copernicus Value (2016): 79. 57 | Impact Factor (2015): 6. 391

away of water in the wells were carried out using a ladle connected to a cord; polyethylene bottles of capacity 1 liter and a refrigerator containing dry ices were used for the transportation and the conservation of the samples. A"YSI" multi parameter was used to measure in situ, the electric conductivity, the $\mathrm{pH}$, the total dissolved salts, and the temperature of ground waters. The statistical data processing was carried out using the Statistica software.

\subsection{Chemical and Bacteriological analysis}

In the laboratory, the major ions $\left(\mathrm{Cl}^{-}, \mathrm{SO}_{4}{ }^{2-}\right)$, total hardness (TH) and nutritive salts were proportioned. The chlorides and alkalinity were proportioned by titration $[\mathbf{2 2}, \mathbf{1}]$. Ions $\mathrm{SO}_{4}{ }^{2-}$ were proportioned by nephelometry. The derivatives nitrogenized on the other hand, were measured by colorimetry using a "Hach DR2010"spectrophotometer, nitrates $\left(\mathrm{NO}_{3}{ }^{-}\right)$by reduction with cadmium, nitrites $\left(\mathrm{NO}_{2}{ }^{-}\right)$ by diazotization and ammonium $\left(\mathrm{NH}_{4}{ }^{+}\right)$by the indophenol method. The microbiological analyses were used to identify and count fecal Streptococcus, total Coliforms, fecalColiforms and Clostridium perfringens. These microorganisms were identified and counted by filtering the homogeneous aliquot of $100 \mathrm{ml}$ on a membrane whose pores diameter is of $0,45 \mu \mathrm{m}$. The membranes were then placed on selective substratum's during 24 hours at $37^{\circ} \mathrm{C}$ in the thermostated drying oven. The following mediums were used: KF gelose for fecal Streptococus, ID coli for the total coliforms, TSN gelose (TryptoneSulphites Neomycin) for Clostridium sulfito-reducer of which most outstanding is Clostridium perfringens.

\subsection{Statistical analyses}

The statistical analysis used is based on the principal componentanalysis (ACP). The ACP STATE is a statistical method (initially of descriptive statistics) the purpose of which is to include and to visualize how the effects of isolated phenomena are priori combine. It is a methodology largely used to interpret the hydrochemical data [13, 27]. The statistical analysis was carried out with 18 samples and 13 variables (temperature, $\mathrm{pH}$, conductivity, $\mathrm{NH}_{4}{ }^{+}, \mathrm{PO}_{4}{ }^{3-}$, $\mathrm{SO}_{4}{ }^{2-}, \mathrm{Cl}^{-}, \mathrm{Ca}^{2+}, \mathrm{Mg}^{2+}, \mathrm{K}^{+}, \mathrm{Na}^{+}, \mathrm{NO}_{3}{ }^{-}$and $\left.\mathrm{NO}^{2-}\right)$. The statistical tests were carried out to know the sources of underground waters pollutions. Initially a simplified analysis of the parameters studied in comparison with standards WHO was made. Then the study of the typology of the well water pollution was made using a Normalized Principal Component Analysis (ACPN). The eigenvalues, the factorial charts and the circles of correlations were obtained with the software Statistica 7. 1. That allow as to treat all numerical characters playing the same role [8].

\section{Results and Discussion}

\subsection{Results}

The studied wells have depths varying between $0,98 \mathrm{~m}$ and $8,38 \mathrm{~m}$. In the village of Anan the depths of the wells vary between $0,98 \mathrm{~m}$ and $7,97 \mathrm{~m}$ with piezometric levels oscillated between $0,5 \mathrm{~m}$ and 7,2 $\mathrm{m}$. The depths of the wells of Agban vary between 1,31 m and 7,03 m with water levels varying between 1,33 and $6,85 \mathrm{~m}$. This proximity of ground water compared to topographic surface reinforces the vulnerable character of the majority of the wells of the various localities of Bingerville. The access to the modern service of cleansing being non-existent in rural zone, the majority of these water points is neighboring of the autonomous drainage systems given up or of use. The average distance between the latrines and the various water points is $19,45 \mathrm{~m}$. the drainage systems are sometimes upstream of wellwaters.

The physical and chemical parameters include the temperature, the $\mathrm{pH}$, the conductivity, the TDS, the dissolved oxygen, the ammonium, the phosphate, the nitrates, the sodium, the calcium and the magnesium. In the zone of study, the temperature does not present great variations of one well at the other (Figure 3A) and remains close to the annual average temperature of the area that is $27^{\circ} \mathrm{C}$, with a minimum of $25,7^{\circ} \mathrm{C}$ in Anan and a maximum of $28,93^{\circ} \mathrm{C}$ in Agban. In these two localities, the $\mathrm{pH}$ varies between 3,83 and 6,05 (Figure 3B). Water of this area has an acid tendency. Acidity is all the more significant in the wells of Anan.

Electric conductivity as for it lies between $64 \mu \mathrm{S} / \mathrm{cm}$ and $1068 \mu \mathrm{S} / \mathrm{cm}$ (Figure 3C). Water of wells $\mathrm{A}_{1}, \mathrm{~A}_{2}, \mathrm{~A}_{3}, \mathrm{~A}_{4}, \mathrm{~A}_{5}$, $\mathrm{A}_{7}, \mathrm{~A}_{8}, \mathrm{~A}_{9}, \mathrm{AG}_{3}$ and $\mathrm{AG}_{4}$ has an electric conductivity higher than the guide value of $\mathrm{WHO}$ which is of $300 \mu \mathrm{S} / \mathrm{cm}$, that is to say $66,67 \mathrm{PC}$ of the analyzed water points. Certain water points are very slightly mineral-bearing with a conductivity lower than $90 \mu \mathrm{S} / \mathrm{cm}$; it is the case of the water sources $S_{1}$ and $S_{2}$ of the village of Agban $(64 \mu \mathrm{S} / \mathrm{cm}$ and $71 \mu \mathrm{S} / \mathrm{cm})$ and of the well $\mathrm{A}_{6}$ of Anan $(85 \mu \mathrm{S} / \mathrm{cm})$. The strong values of conductivity were noted with the wells $\mathrm{A}_{1}, \mathrm{~A}_{2}, \mathrm{~A}_{3}, \mathrm{~A}_{4}, \mathrm{~A}_{5}$, $A_{7}, A_{8}, A_{9}$ and $A_{3}$ whose values lie between $457 \mu \mathrm{S} / \mathrm{cm}$ and $1068 \mu \mathrm{S} / \mathrm{cm}$. 
International Journal of Science and Research (IJSR)

ISSN (Online): 2319-7064

Index Copernicus Value (2016): 79. 57 | Impact Factor (2015): 6. 391
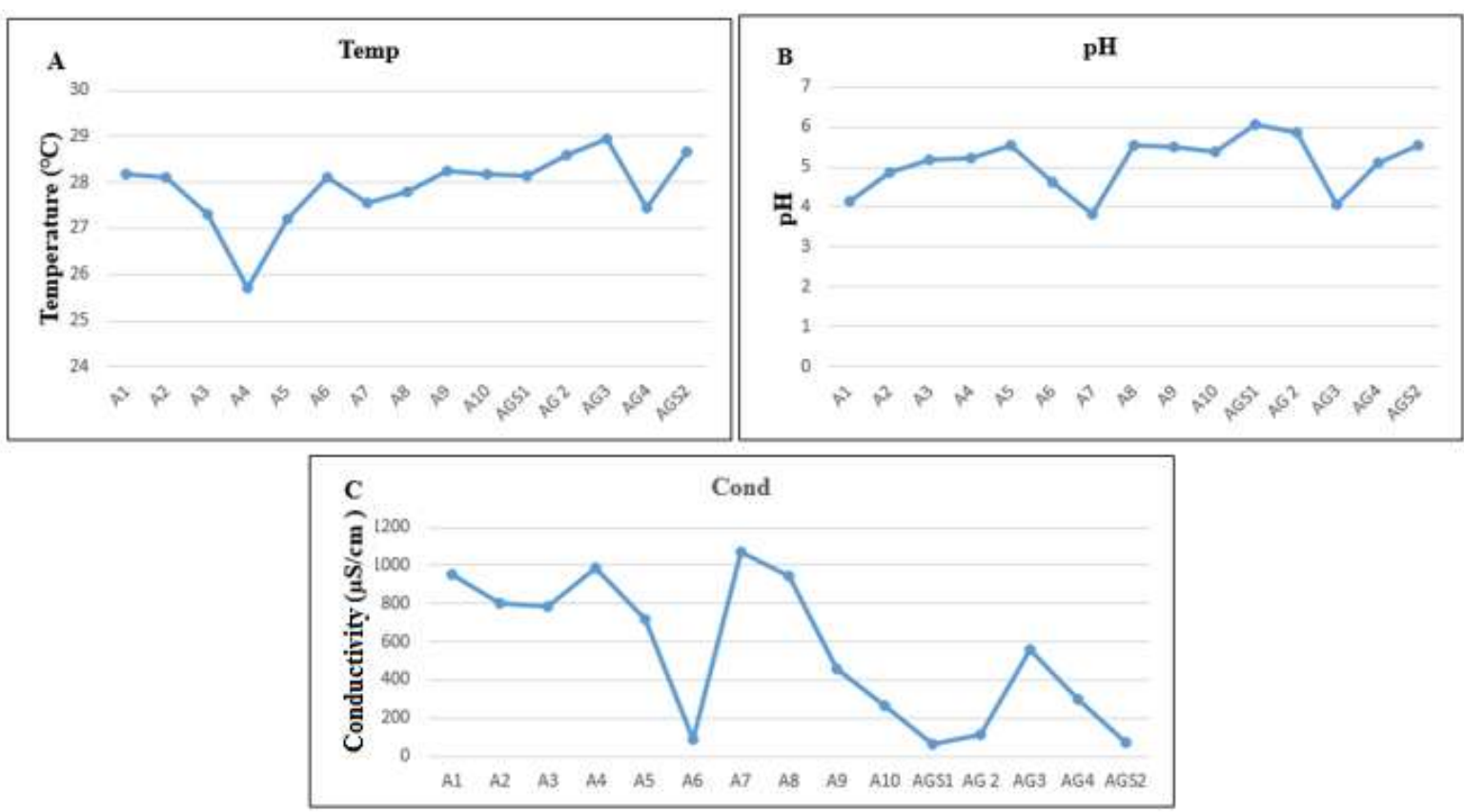

Figure 3: Spatial evolution of the physical parameters: temperature (A); $\mathrm{pH}(\mathrm{B})$;conductivity $(\mathrm{C})$ in Anan and Agban

Concentrations in ions $\mathrm{NH}_{4}{ }^{+}, \mathrm{PO}_{4}{ }^{3-}, \mathrm{SO}_{4}{ }^{2-}$ and $\mathrm{NO}_{3}{ }^{-}$and the thresholds values in the wells of Anan and Agban are indicated in table 1. These parameters are pollution indicators and suggested the worse quality of water of domestic use. The concentrations of the well water of Agbanin ammonium are lower than $0,5 \mathrm{mg} / \mathrm{l}$. That is not the case with Anan where one observes ammonium peaks going up to $2,2 \mathrm{mg} / \mathrm{l}$. The phosphate concentrations are high in all the wells of Anan and four wells out of five in Agban that also have their phosphate concentration high. The values of this parameter in studied water are very variable and oscillate between $0,004 \mathrm{mg} / \mathrm{l}$ and $1,01 \mathrm{mg} / \mathrm{l}$. The analysis of the nitrates contents of the wells shows a slight variation which oscillates between $0,4 \mathrm{mg} / \mathrm{l}$ and $28 \mathrm{mg} / \mathrm{l}$ and which remains lower than the threshold value of WHO $(50 \mathrm{mg} / \mathrm{l})$. So studied water is not subjugated at the risk of pollution by nitrates.

Table I: Statistical synopsis of the concentrations of the indicator ions of pollution of the wells of Anan and Agban

\begin{tabular}{|c|c|c|c|c|}
\hline Ions & Min (mg/l) & $\begin{array}{c}\text { Average } \\
(\mathrm{mg} / \mathrm{l})\end{array}$ & $\begin{array}{c}\text { Max } \\
(\mathrm{mg} / \mathrm{l})\end{array}$ & $\begin{array}{c}\text { limit Value } \\
(\mathrm{mg} / \mathrm{l})\end{array}$ \\
\hline $\mathrm{NH}_{4}{ }^{+}$ & $<0,01$ & 0,298 & 2,2 & 0,5 \\
\hline $\mathrm{PO}_{4}{ }^{-}$ & $<0,004$ & 0,2736 & 1,01 & 0,005 \\
\hline $\mathrm{NO}_{3}{ }^{-}$ & 0,4 & 6,67 & 28 & 50 \\
\hline
\end{tabular}

\begin{tabular}{|c|c|c|c|c|}
\hline $\mathrm{SO}_{4}{ }^{2-}$ & 1,18 & 23,56 & 129,58 & 250 \\
\hline
\end{tabular}

The results of the statistical analysis (ACP) give many tables of which some are summarized in this study. The table of the eigenvalues (Table II) shows that the first three factors account for 84,90 PC of the expressed variance. They can thus make it possible to interpret the results obtained.

Table II: Eigen values and percentages of the variances expressed by the principal axes

\begin{tabular}{|c|c|c|c|c|}
\hline & $\begin{array}{c}\text { Eigen } \\
\text { value }\end{array}$ & $\begin{array}{c}\text { Total PC } \\
\text { Variance }\end{array}$ & $\begin{array}{c}\text { Cumul } \\
\text { Engenvalue }\end{array}$ & Cumul (\%) \\
\hline F1 & 7.656212 & 58.89393 & 5,23662 & 58.8939 \\
\hline F2 & 2.055069 & 15.80823 & 9.71128 & 74.7022 \\
\hline F3 & 1.326681 & 10.20524 & 11.03796 & 84.9074 \\
\hline
\end{tabular}

The matrix of correlation (Table III) shows the various correlations between the studied physicochemical parameters. This matrix highlights significant correlations between conductivity, ammonium, nitrates, sulphate, potassium, sodium, calcium, magnesium and the ions chlorides. The matrix also reveals a correlation between magnesium and calcium $(\mathrm{R}=0,89)$; between potassium and sodium $(\mathrm{R}=0,94)$ and between the ions chlorides and the sulphate $(\mathrm{R}=0,95)$.

Table III: Correlations between the physicochemical parameters of water

\begin{tabular}{|l|l|l|l|l|l|l|l|l|l|l|l|l|l|}
\hline & $\mathrm{NO}_{2}{ }^{-}$ & $\mathrm{NH}_{4}^{+}$ & $\mathrm{PO}_{4}{ }^{3-}$ & $\mathrm{NO}_{3}{ }^{-}$ & $\mathrm{pH}$ & $\mathrm{T}^{\circ} \mathrm{C}$ & $\mathrm{SO}_{4}{ }^{--}$ & $\mathrm{Cl}^{-}$ & $\mathrm{Ca}^{2+}$ & $\mathrm{K}^{+}$ & $\mathrm{Mg}^{2+}$ & $\mathrm{Na}^{+}$ & $\mathrm{Cond}^{-}$ \\
\hline $\mathrm{NO}_{2}{ }^{+}$ & 1 & & & & & & & & & & & & \\
\hline $\mathrm{NH}_{4}{ }^{3-}$ & 0.17 & 1 & & & & & & & & & & & \\
\hline $\mathrm{PO}_{4}{ }^{-}$ & $\mathbf{0 . 7 0}$ & 0.24 & 1 & & & & & & & & & & \\
\hline $\mathrm{NO}_{3}{ }^{-}$ & -0.11 & 0.23 & -0.19 & 1 & & & & & & & & & \\
\hline $\mathrm{pH}$ & -0.08 & -0.34 & 0.16 & -0.73 & 1 & & & & & & & & \\
\hline $\mathrm{T}^{0} \mathrm{C}$ & -0.06 & -0.74 & -0.43 & -0.02 & -0.05 & 1 & & & & & & & \\
\hline $\mathrm{SO}_{4}{ }^{2-}$ & 0.10 & 0.59 & 0.26 & 0.33 & -0.23 & -0.59 & 1 & & & & & & \\
\hline $\mathrm{Cl}^{-}$ & 0.13 & 0.61 & 0.23 & 0.31 & -0.28 & -0.59 & 0.95 & 1 & & & & & \\
\hline $\mathrm{Ca}^{2+}$ & 0.21 & 0.79 & 0.30 & 0.50 & -0.32 & -0.72 & 0.80 & 0.82 & 1 & & & & \\
\hline $\mathrm{K}^{+}$ & 0.08 & 0.62 & 0.20 & 0.45 & -0.39 & -0.60 & 0.93 & 0.94 & 0.86 & 1 & & & \\
\hline $\mathrm{Mg}^{2+}$ & 0.08 & 0.41 & 0.05 & 0.42 & -0.26 & -0.36 & 0.80 & 0.89 & 0.78 & 0.86 & 1 & & \\
\hline $\mathrm{Na}^{+}$ & 0.13 & 0.61 & 0.23 & 0.31 & -0.29 & -0.59 & 0.95 & 1 & 0.82 & 0.94 & 0.89 & 1 & \\
\hline $\mathrm{Cond}^{2}$ & 0.27 & 0.66 & 0.25 & 0.59 & -0.48 & -0.52 & 0.89 & 0.91 & 0.92 & 0.92 & 0.86 & 0.91 & 1 \\
\hline
\end{tabular}

\title{
Volume 6 Issue 12, December 2017
}

\author{
www. ijsr. net
}

Licensed Under Creative Commons Attribution CC BY 


\title{
International Journal of Science and Research (IJSR) \\ ISSN (Online): 2319-7064
}

Index Copernicus Value (2016): 79. 57 | Impact Factor (2015): 6. 391

The analysis of the factorial axis (Figure 4) also reveals a correlation between the physicochemical parameters of studied water. Thus, the factor $F_{1}$ in the factorial axes $F_{1}-F_{2}$ and $F_{1}-F_{3}$ is determined by conductivity, potassium, sodium, sulphate, magnesium, calcium, ammonium and the ions chlorides. This axis can be compared to the mineral character of water on which depend the parameters indicated below. The axis $F_{3}$ in the factorial axis $F_{1}-F_{3}$ is defined by, the phosphate, the nitrates and the nitrites. This factor expresses the water pollution by the anthropic activities and the intrusion of brackish water in the ground water. The factor $\mathrm{F}_{2} \mathrm{in}$ the axis $\mathrm{F}_{1}-\mathrm{F}_{2}$ is defined by the $\mathrm{pH}$, phosphate and nitrites.

The factorial chart of the wells (Figure 4) makes it possible to gather this water in three classes. Class 1 is characterized by strongly mineralized well water. The rock salt high concentrations $\left(\mathrm{SO}_{4}{ }^{2-}, \mathrm{Cl}^{-}, \mathrm{K}^{+}\right.$and $\left.\mathrm{Na}^{+}\right)$are strongly affected by the anthropic activity. The conductivity of the wells of this class lies between $716 \mu \mathrm{S} / \mathrm{cm}$ and $1060 \mu \mathrm{S} / \mathrm{cm}$. The $\mathrm{pH}$ of this water lies between 3,8 and 5. 56. One finds these wells primarily in Anan $\left(\mathrm{A}_{1}, \mathrm{~A}_{2}, \mathrm{~A}_{3}, \mathrm{~A}_{4}, \mathrm{~A}_{5}, \mathrm{~A}_{7}\right.$ and $\left.\mathrm{A}_{8}\right)$. 28PC of the wells of class 1 have ammonium concentrations higher than $0,5 \mathrm{mg} / \mathrm{l}$ and all the wells present the higher phosphate rates than the threshold value of WHO $(0,005 \mathrm{mg} / \mathrm{l})$. The average distance between the latrines and the various water points is $16 \mathrm{~m}$.

Class 2 is characterized by fairly mineralized water with a conductivity ranging between $263 \mu \mathrm{S} / \mathrm{cm}$ and $555 \mu \mathrm{S} / \mathrm{cm}$. The ammonium concentrations in these wells are lower than $0,5 \mathrm{mg} / \mathrm{l}$ with phosphate rates higher than $0,005 \mathrm{mg} / \mathrm{l}$. The wells concerned are: $\mathrm{A}_{9}$ and $\mathrm{A}_{10}$ (Anan); $\mathrm{AG}_{3}$ and $\mathrm{AG}_{4}$ (Agban).

Class 3 is characterized by water slightly mineralized of the sedimentary basin. The concentrations of rock salt are weak with a conductivity ranging between $64 \mu \mathrm{S} / \mathrm{cm}$ and 117 $\mu \mathrm{S} / \mathrm{cm}$. The ammonium concentrations in these wells are lower than $0,5 \mathrm{mg} / 1 . \quad 75 \mathrm{PC}$ of the wells of this class show phosphate rates higher than $0,005 \mathrm{mg} / \mathrm{l}$ (the threshold value of WHO). These wells are much affected by the anthropic activities with an average distance of $18.52 \mathrm{~m}$ separating them from the septic tanks. At that is added the infiltration of brackish water coming from the Ebrié lagoon which is at $8 \mathrm{~m}$ of wells $\left(\mathrm{AGS}_{1}, \mathrm{AGS}_{2}, \mathrm{AG} 2\right.$ and A6)

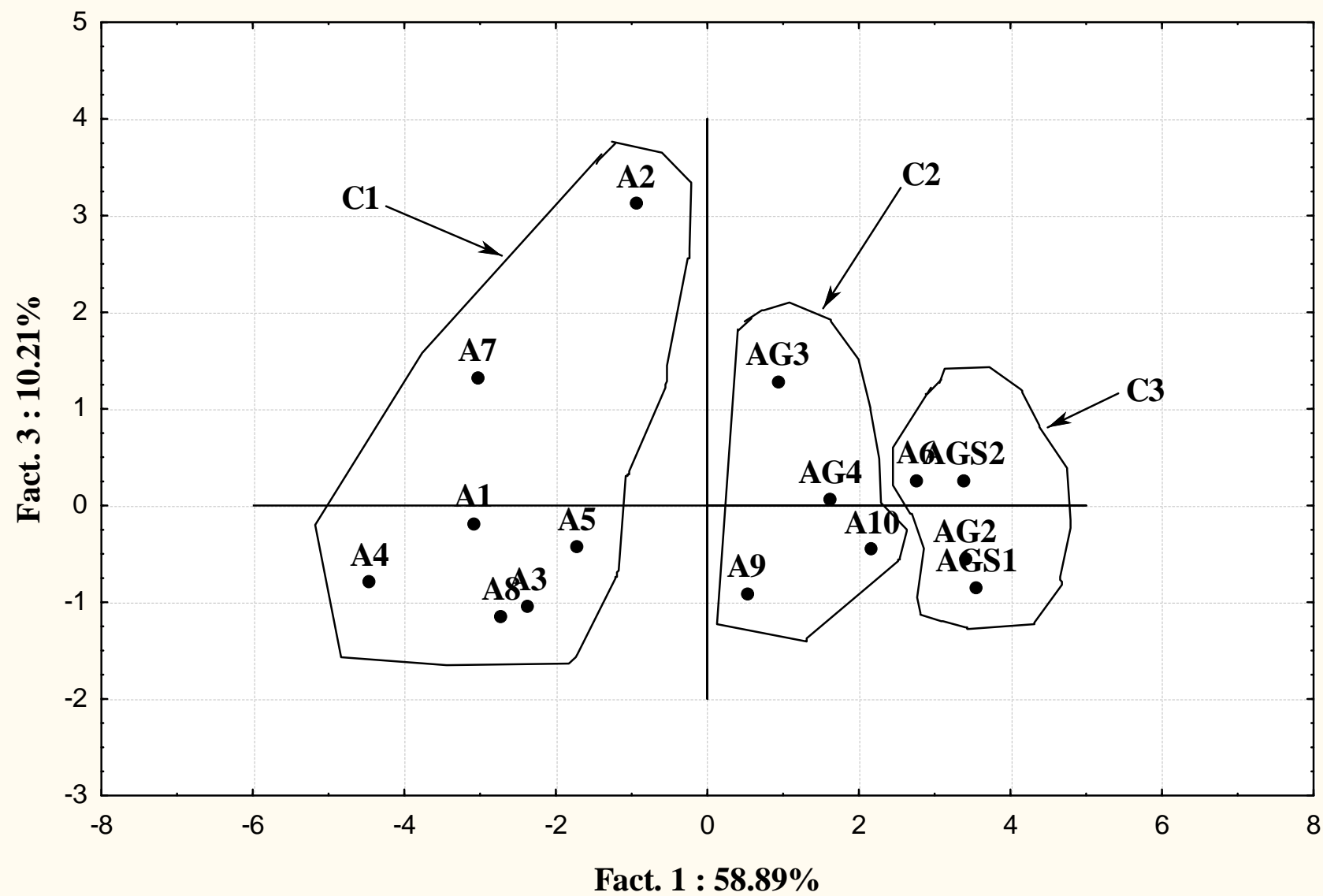

Figure 4: Graphic representation of the factorial chart of the wells of Anan and Agban

The microbiological analyses show the presence of the bacteria of the total coliforms types, fecalcoliforms, fecal streptococcus and Clostridium perfringens in sampled ground waters (Figures 5 and 6). The total coliforms are present in all the wells of the visited localities. The total concentrations of coliforms vary from $930 \mathrm{UFC} / 100 \mathrm{ml}$ to $245000 \mathrm{UFC} / 100 \mathrm{ml}$ with an average of $28093 \mathrm{UFC} / 100 \mathrm{ml}$ in Anan and $180 \mathrm{UFC} / 100 \mathrm{ml}$ to $15200 \mathrm{UFC} / 100 \mathrm{ml}$ with an average of $4356 \mathrm{UFC} / 100 \mathrm{ml}$ in Agban. The fecal concentrations of coliforms vary from 70 to $37000 \mathrm{UFC} / 100$ $\mathrm{ml}$ with an average of $4427 \mathrm{UFC} / 100 \mathrm{ml}$ in Anan and 10 to $4100 \mathrm{UFC} / 100 \mathrm{ml}$ in Anan with an average of 1118 UFC/100 ml. These bacteria are good indicators of recent fecal contaminations. All the visited wells are contaminated

\section{Volume 6 Issue 12, December 2017}

\author{
www. ijsr. net
}




\section{International Journal of Science and Research (IJSR) \\ ISSN (Online): 2319-7064}

Index Copernicus Value (2016): 79. 57 | Impact Factor (2015): 6. 391

by the fecal coliforms. The fecal streptococcus ones are also present in all analyzed waters. Their concentrations vary from $20 \mathrm{UFC} / 100 \mathrm{ml}$ to $1050 \mathrm{UFC} / 100 \mathrm{ml}$ with an average of $231 \mathrm{UFC} / 100 \mathrm{ml}$ in Anan and from 30 to $2680 \mathrm{UFC} / 100$ $\mathrm{ml}$ with an average of $1228 \mathrm{UFC} / 100 \mathrm{ml}$ in Agban. These bacteria are also good indicators of fecal contamination. Clostridium perfringens are present in 6 water samples on
15 well that is to say $40 \mathrm{PC}$ of sampled waters. The concentrations vary from 2 to $34 \mathrm{UFC} / 20 \mathrm{ml}$ than 10 to 170 $\mathrm{UFC} / 100 \mathrm{ml}$ with an average of $24 \mathrm{UFC} / 100 \mathrm{ml}$ in Anan, and from 0 to $20 \mathrm{UFC} / 100 \mathrm{ml}$ for an average of $2 \mathrm{UFC} / 100$ $\mathrm{ml}$ in Agban.

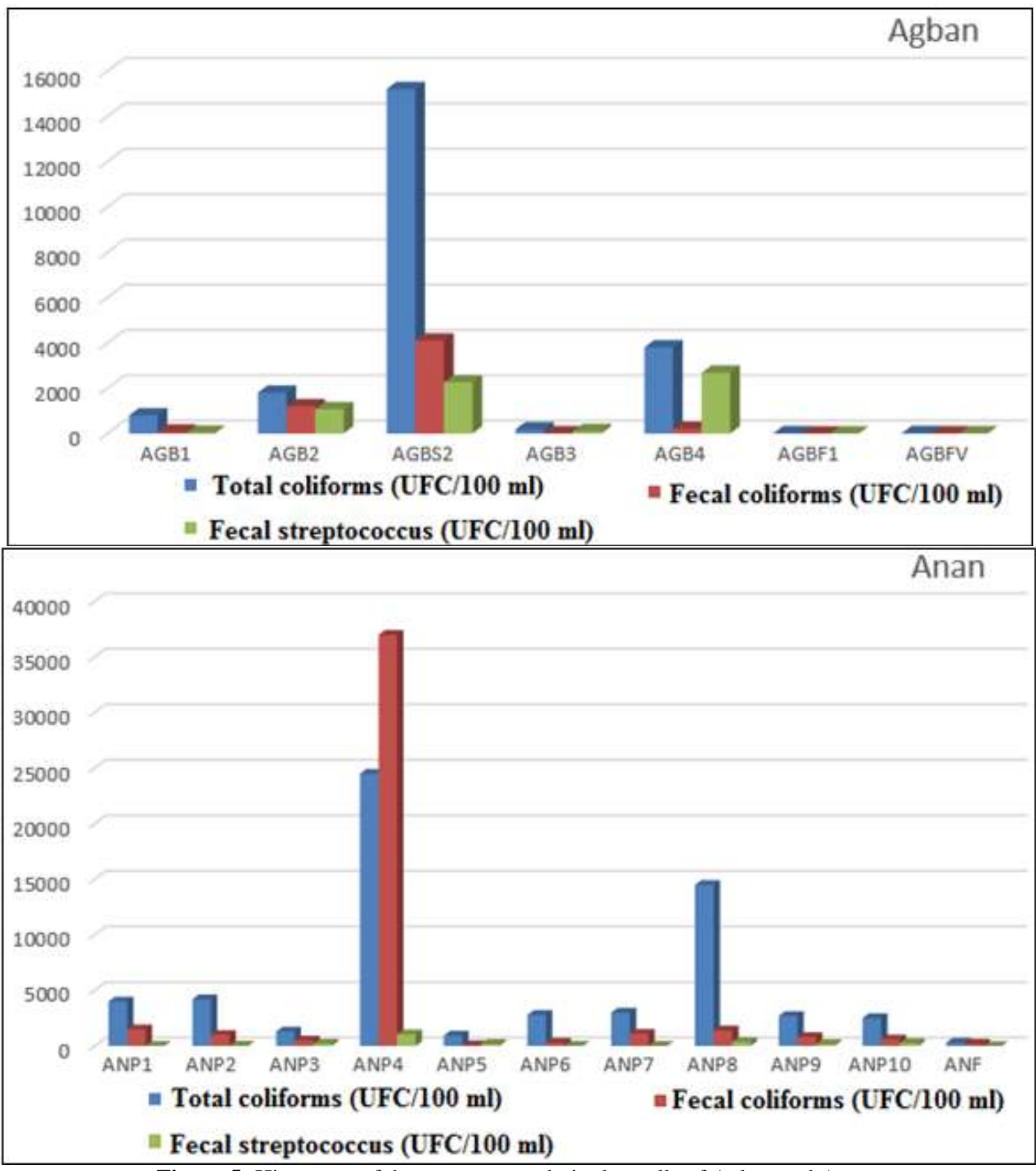

Figure 5: Histogram of three germs sought in the wells of Agban and Anan.

Volume 6 Issue 12, December 2017 www. ijsr. net 
International Journal of Science and Research (IJSR)

ISSN (Online): 2319-7064

Index Copernicus Value (2016): 79. 57 | Impact Factor (2015): 6. 391

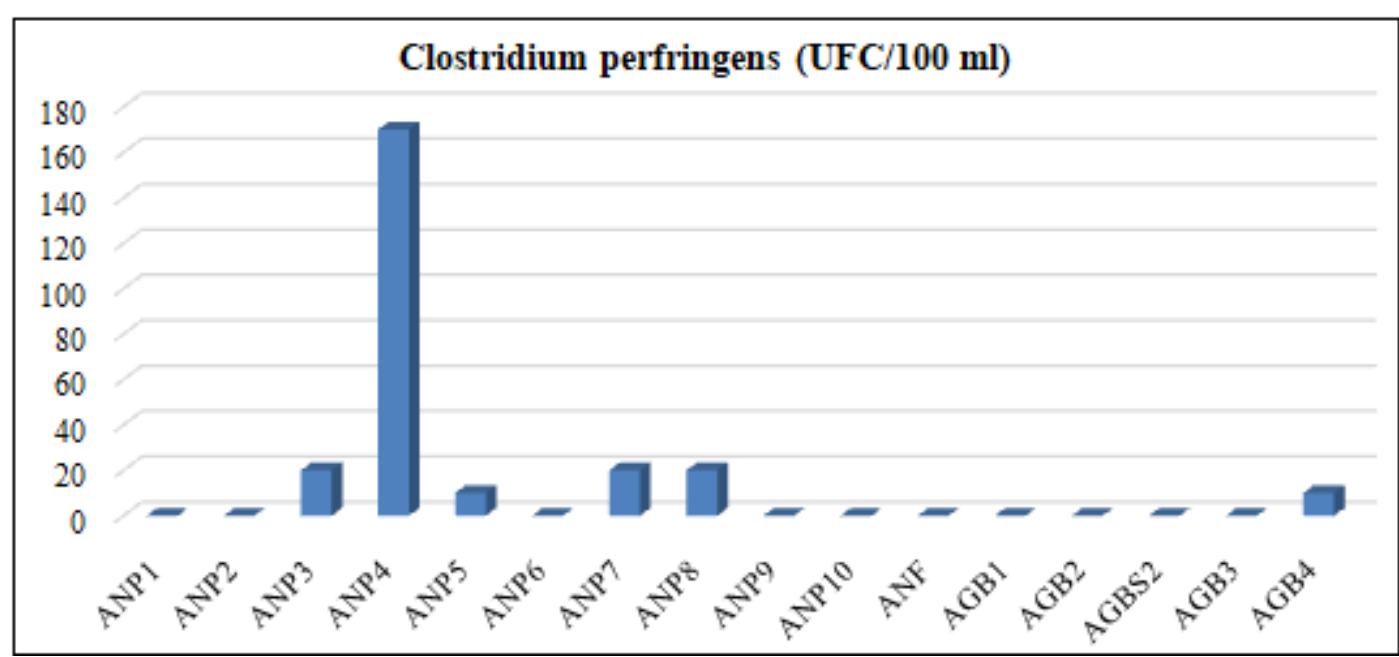

Figure 6: Variation of the rates of Clostridium perfringens in the various wells

\subsection{Discussion}

Studied water has average temperatures of $27,63^{\circ} \mathrm{C}$ and $28,36^{\circ} \mathrm{C}$. These temperatures which correspond to the seasonal variations of the ambient temperatures register in the interval of the values defined by [21] and [4] in ground waters of the area of Abidjan and it neighboring's (25,5 to $30,4^{\circ} \mathrm{C}$ ). [12] justified these temperatures found by the fact that in wet tropical zone, the average temperature of water is of approximately $30^{\circ} \mathrm{C}$. These values of temperature indicate the opening of the aquiferous system thus, therefore its vulnerability opposite with pollution [24]. Water is acid, with an average $\mathrm{pH}$ of 4,99 for Anan verses 5,32 for Agban. Indeed, in wet tropical zone, this acidity comes mainly from the decomposition of the organic vegetable matter, with the production of $\mathrm{CO}_{2}$ in the first layers of ground $[\mathbf{1 9}, 4]$. Strong values of conductivity were noted primarily in the wells of Anan $\left(A_{1}, A_{2}, A_{3}, A_{4}, A_{5}, A_{7}\right.$ and $\left.A_{8}\right)$. These values lie between $716 \mu \mathrm{S} / \mathrm{cm}$ and $1060 \mu \mathrm{S} / \mathrm{cm}$. The value of conductivity is influenced by various natural and anthropic factors amongst other things, the geology of the catchment area (the composition of the rocks), contributions of ground waters and contributions of contaminated water coming from the human activities [16]because the contaminated rejections increase also the conductivity of water [25].

The quality of a ground water is characterized by the concentrations in ions $\mathrm{NH}_{4}{ }^{+}, \mathrm{PO}_{4}^{3-}, \mathrm{SO}_{4}{ }^{2-}$ and $\mathrm{NO}_{3}^{-}$. The standards of WHO (the World Health Organization) and the European union (UE) define the limiting values of $\mathrm{NH}_{4}{ }^{+}$, $\mathrm{PO}_{4}{ }^{3-}, \mathrm{SO}_{4}{ }^{2-}$ and $\mathrm{NO}_{3}{ }^{-}$which are respectively $0,5 \mathrm{mg} / 1,0,005$ $\mathrm{mg} / \mathrm{l}, 50 \mathrm{mg} / \mathrm{l}$ and $250 \mathrm{mg} / \mathrm{l}$ in a drink water.

One observes raised out concentrations of ammonium in the village of Anan with peaks of $2,2 \mathrm{mg} / \mathrm{l}$. That is definitely higher than the threshold value recommended by WHO $(0,5$ $\mathrm{mg} / \mathrm{l}$ ) for a drink water. Ammonium is a nitrogenized component whose presence in a ground water results from a surface contamination primarily related to the domestic and industrial effluents rejections or of a natural reduction phenomenon of nitrates [3]. One notes the presence of phosphate in all the sampled wells. The phosphate concentrations vary between $0,004 \mathrm{mg} / \mathrm{l}$ and $1.01 \mathrm{mg} / \mathrm{l} .93$ PC of the wells present a higher phosphate concentrations than the threshold value of WHO $(0,005 \mathrm{mg} / \mathrm{l})$. This could come from the rejections of worn water and the discharges of house refuse [20]. Nitrate average concentrations of the wells in Anan and Agban are respectively of $7,47 \mathrm{mg} / \mathrm{l}$ and $5,08 \mathrm{mg} / \mathrm{l}$, values largely lower than the threshold value of WHO $(50 \mathrm{mg} / \mathrm{l})$. Thus, the low contents met in water of Anan and Agban could be explained by the fact that these localities do not shelter any agro-industrial exploitation using significant quantities of manure.

The multivariate statistical analysis of the hydrochemical data (ACP), reveals on the basis of correlation existing between the various elements, the principal mechanisms being responsible for the evolution of the mineralization of water of the localities to be visited. The correlation of conductivity with the major ions accounts for the mineralization or the minerals hydrolysis phenomenon [4]. It should be noted that conductivity described inorganic salts present in water solution. The correlation between magnesium and calcium $(R=0,811)$ reflects the dissolution of the rocks related to the residence time of water in the aquifer [4]. However, the zone of study belongs to the sedimentary basin of the Continental Terminal (southern of the country) and primarily consists of clayey sands and sandstone dating from the tertiary sector, precisely of the pliocen [23]. With that the fact is added that sampled water is primarily ground water most exposed to the seasonal rainfall fluctuations, the residence time of water in contact with these rocks is very limited [11]. That explains the weak magnesium and calcium rates. Water thus does not have enough time to exchange with certain parameters of the hosts rocks. The mineralization phenomenon related to the rock is very weak. The correlation between potassium and sodium $(\mathrm{R}=0,814)$ and between the ions chlorides and the sulphate $(R=0,522)$ highlight the salinization due to the proximity of the latrines and the intrusion of brackish water in the ground water [11]. The results of the various microbiological analyses show that this water is unsuitable for human consumption because water of well presents a strong contamination by germs of fecal origin and the standards of WHO require the total absence of fecal contamination germs in the water intended for the drink [26].

The localities of Agban and Anan use for its food drinking water the deep nap through the water towers offered by the

\section{Volume 6 Issue 12, December 2017}




\section{International Journal of Science and Research (IJSR) \\ ISSN (Online): 2319-7064}

Index Copernicus Value (2016): 79. 57 | Impact Factor (2015): 6. 391

district of Abidjan. However in the event of breakdown these localities turn to wells water and sources which present high bacterial loads. The studied wells have depths alternatives between $0,98 \mathrm{~m}$ and $8,38 \mathrm{~m}$ with piezometric levels which oscillate between $0,5 \mathrm{~m}$ and $7,2 \mathrm{~m}$. This proximity of ground water compared to topographic surface reinforce the vulnerable character of the majority of the wells of the various localities of Bingerville. The studies undertaken by [20] on well water of Dang in Cameroun, confirm this assertion according to which the depth of the wells and the distance between those and the latrines influence the proliferation of the germs in water. The microbiological analyses show the presence of the bacteria of total coliformstypes, fecal coliforms, fecal streptococcus and Clostridium Perfringens in well water of Anan and Agban. All the visited wells are contaminated by the fecal germs. That translates the defect of cleansing of the aria which exposes the water resources to strong contaminations of bacteria of fecal origin [28]. According to [15], the presence of the spores of the anaerobes sulfite-reducers in natural water makes think of a fecal contamination and in the absence of Coliforms bacteria, with an old contamination. They are very persistent and their presence is a good indicator of the vulnerability of the aquifers and wells [6]. The presence of Clostridium sulfite-reducers is very significant of an old or intermittent fecal pollution. The microbial load present in analyzed well water could be justified by a certain number of factors inherent to the agropastorals activities around the wells, a defect of installation of these wells, the proximity of the pollution sources such as the house refuse, the latrines, the septic tanks and the nonobservance of the rules of elementary hygiene by users [20].

\section{Conclusion}

The data collected during this study reveals physicochemical and bacteriological quality ground waters of Bingerville. The spring waters, of well and drillings are still significant sources of supply water for these villages. They are intended for various uses (drink, detergents, crockery and especially in the food and the drenching of the animals). The analyzed water points are generally acid $(\mathrm{pH}<7)$ and have a temperature which varies between $25,7^{\circ} \mathrm{C}$ and $28,9^{\circ} \mathrm{C}$. Electric conductivities included64 $\mu \mathrm{S} / \mathrm{cm}$ and $1068 \mu \mathrm{S} / \mathrm{cm}$. This study also revealed the presence of ions which are indicators of pollution. The parameters more threatening remain the phosphate $\left(\mathrm{PO}_{4}{ }^{2-}\right)$ and the ammonium $\left(\mathrm{NH}_{4}{ }^{+}\right)$ whose averages remain strongly high. On the bacteriological level, all analyzed water (except water of drillings) is infected by the germs of fecal contamination and do not have to be consumed without treatment. This pollution most probably finds its origins in the insufficiency of the infrastructures of cleansing, the collection of the house refuse and the brackish water infiltrations in the ground water.

\section{References}

[1] AFNOR (Association française de normalisation) (1997). Qualité de l'eau : terminologie échantillonnage etEvaluation des Méthodes (Tome 1, 3 édition). AFNOR : Paris, France.
[2] Ahoussi, K. E. , Koffi, Y. B. , Kouassi, A. M. , Soro, G , \&Biemi, J. , (2013). Études hydrochimiques et microbiologique des eaux de source de l'ouest montagneux de la Côte d'Ivoire : Cas du village de Mangouin-Yrongouin (sous-préfecture de Biankouman). J. Appl. Biosci. 63 : 4703-4719.

[3] Ahoussi, K. E. , Loko, S. , Koffi, Y. B. , Soro, G. , Oga, Y. M. S. , \&Soro, N. (2013). Evolution spatiotemporelle des teneurs en nitrates des eaux souterraines de la ville d'Abidjan (Côte d'ivoire). Int. J. Pure App. Biosci. 1 (3) : 45-60.

[4] Ahoussi K. E. , Soro N. , Koffi Y. B. , Soro G. ,\&Biémi, J. (2010). Origine de la minéralisation des eaux des aquifères discontinus sous couvert forestier de la zone Sud de la Côte d'Ivoire: cas de la région d'AbidjanAgboville. International Journal of Biological and Chemical Sciences, 4(3): 782-797

[5] ATLAS COTE D'IVOIRE. (1986). Atlas de Côted'Ivoire. Ministère du plan de Côte-d'Ivoire. Office de la recherche scientifique et technique outre-mer. Institut de géographie tropicale. Université d'Abidjan. 67 p.

[6] Ayad W. ,\&Kahoul, M. (2016). Evaluation de la qualité physico chimique et bactériologique des eaux de puits dans la région d'El Harrouch (N. E Algérie). J. Mater. Environ. Sci. 7(4) : 1288-1298.

[7] Belghiti, M. L. , Chahlaoui A. , Bengoumi, D. , \& ELMoustaine, R. (2013). Étude de la qualité physicochimique et bactériologique des eaux souterraines de la nappe plio-quaternaire dans la région de Meknès. Larhyss Journal, 14 : 21-36

[8] Bouroche J. M. ,\&Saporta G. (1992). L'analyse des Données (Collection Que sais-je ? n`854, 5 -ème édition). Presses Universitaires de France : Paris ; 1-27.

[9] Caillez J. P. , \&Pages (1976). Introduction à l'Analyses des données. SMASH, Paris, 616 p.

[10] Coulibaly, L. , Diomandé, D. , Coulibaly, A. ,\&Gourène G. 2004. Utilisation desressources en eaux, assainissement etrisques sanitaires dans les quartiersprécaires de la commune de PortBouët(Abidjan; cote d'ivoire). Vertigo - La Revue en Sciences de l'Environnement,

[11]Dibi B. , Konan K. S. , Konan-Waidhet A. B. , Savané I. , \&Gnakri D. (2014). Analysis of the impact of anthropic activities on the water chemistry of weathered layer aquifer of M'bahiakro locality (Center of Côte d'Ivoire). American Journal of Engineering Research (AJER), 3 (1) : 43-49.

[12] Eblin S. G. , Sombo A P. , Soro G. , Aka N. , Mbiré O. , \& Oro N. (2014). Hydrochimie des eaux de surface de la région d'Adiaké (sud-est côtier de la Côte d'Ivoire). Journal of Applied Biosciences 75 : 6259-6271 ISSN 1997-5902.

[13]El Asslouj, J. , Kholtei S. , El Amrani-Paaza N. , \&Hilali A. (2007). Impact des activités anthropiques sur la qualité des eaux souterraines de la communauté Mzamza (Chaouia, Maroc). Rév. Sci. Eau,20 (3) : 306321.

[14]Fofana, F. (2005). Evaluation et cartographie de la vulnérabilité à la pollution de la nappe d'Abidjan selon les méthodes Drastic et God. Mém. DEA, Univ. AboboAdjamé, Côte d'Ivoire. 72p.

[15] Guessoum, H. , Benbrahim, F. , Halilat, M. T. , Laouar F. , Bensalama M. , \&Darem, S. (2014). Pollution 
Biologique des Eaux Phréatiques de la Région de Ghardaia (Cas de Sebseb). Journal of Advanced research and science and technology. $3: 35-43$.

[16] Hade, A. (2002). Nos lacs-les connaître pour mieux les protéger. Éditions Fides, 360p.

[17] INS (Institut national de la statistique). (2014). Recensement général de la population et de l'habitat de Côte d'Ivoire. Rapport de synthèse, volume des fiches monographiques des localités : région des lagunes. INS Abidjan, $50 \mathrm{p}$.

[18] Jourda, J. P. , Kouamé, K. J., Saley M. B. , Kouadio B. H. ,\&Oga Y. S. (2006). Contamination of the Abidjan Aquifer by sewage: An assessment of extent and strategies for protection In Groundwater Pollution inAfrica. Yongxin X, Brent U (eds). Taylor.

[19] Matini, L. , Moutou, J. M. ,\& Kongo-Mantono, M. S. (2009). Évaluation hydrochimique des eaux souterraines en milieu urbain au Sud-Ouest de Brazzaville, Congo. Afrique Science 05(1) : 82-98.

[20] Mbawala, A. , Ngassoum A. ,\&Ngassoum M-B. (2010). Evaluation de la pollution physico-chimique et microbienne des eaux de puits de Dang-Ngaoundéré (Cameroun). Int. J. Biol. Chem. Sci. 4(6) : 1962-1975.

[21] Oga, M. S. (1998). Ressources en eaux souterraines dans la région $d u$ Grand Abidjan (Côte d'Ivoire) : Approche Hydrochimiques et Isotopique. Thèse d'Université d'Orsay, Paris, France. 311p.

[22] Rodier, J. , Bazin, C. , Chanbon, P. , Broutin, J. P. , Champsaur, H. ,\&Rodi, L. (1996). L'analyse de l'eau : eaux naturelles, eaux résiduaires et eaux de mer. $8{ }^{\text {ème }}$ Ed. Dunod, Paris : $1383 \mathrm{p}$.

[23] Tagini, B. (1971). Esquisse structurale de la Côted'Ivoire. Essai de géotectonique régionale. Thèse de Doctorat d'Université de Lausanne (Suisse). Bulletin, SODEMI, $\mathrm{n}^{\circ}$ 5, 302p.

[24] Tandia, A. A. ,Diop, E. S. , \&Gaye, C. B. (1999). Pollution par les nitrates des nappes phréatiques sous environnement semi-urbain non assaini : exemple de la nappe de Yeumbeul, Sénégal. Journal of African Earth Sciences, 29(4) : 809-822.

[25]WASC (WaterwatchAutralia Steering Committee) (2003). Waterwatch Australia National Technical Manual. Environment Australia, 156p.

[26] WHO (World Health Organization) (2008). Guidelines for drinkink-water quality. Third edition incorporating the first and second addenda, volume 1, Recommandations, Geneva.

[27] Yapo, O. B. , Mambo, V. , Seka, A., Ohou, M. J. A. , Konan, F. , Gouzile, V. , Tidou, A. S. , Kouame, K. V., \&Houenou, P. (2010). Evaluation de la qualité des eaux de puits à usage domestique dans les quartiers défavorisés de quatre communes d'Abidjan (Côte d'Ivoire) : Koumassi, Marcory, Port-Bouet et Treichville. Int. J. Biol. Chem. Sci. 4(2) : 289-307.

[28] Youmbi, J. G. T. , Feumba, R. , Njitat V. T. , Marsily, G. , \&Ekodeck, G. E. (2013). Pollution de l'eau souterraine et risques sanitaires à Yaounde au Cameroun. Comptes Rendus Biologies. 336 (5-6) : 310316.

Volume 6 Issue 12, December 2017

www. ijsr. net 